\title{
Proceedings of the
}

\section{CAMBRIDGE PHILOSOPHICAL SOCIETY}

(MATHEMATICAL AND PHYSICAL SCIENCES)

VOLUME 66

PART 2

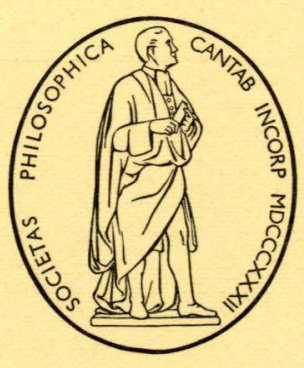

CAMBRIDGE UNIVERSITY PRESS

BENTLEY HOUSE, 200 EUSTON ROAD, LONDON, N.W.1 AMERICAN BRANCH: 32 EAST 57TH STREET, NEW YORK, N.Y.10022

Price Fifty-five Shillings Net (U.S.A. \$9.50)

Subscription price $£ 710$ s. per volume ( $£ 15$ per annum) net post free

(\$24.50 per volume (\$49.00 per annum) in U.S.A.) 
CAMBRIDGE PHILOSOPHICAL SOCIETY

FOUNDED 1819; Royal Charter 1832

\title{
Session 1968-1969
}

\author{
President: J. A. RATCLIF FE \\ Vice Presidents: SIR RUDOLPH PETERS, F. G. YOUNG, \\ SIR GEOFFREY TAYLOR
}

Treasurer: R. C. EVANS

Secretaries: (Mathematical) C. R. F. MAUNDER

(Physical) J. E. FIELD

(Biological) M. A. MESSAGE

The publications of the Society consist of the Proceedings and of the Biological Reviews. The publication of Transactions was suspended at the end of Volume XXIII.

Orders should be sent to: The Manager, Cambridge University Press, Benthey HOUSE, 200 EUSTON ROAD, LONDON, N.W.1. Enquiries from the U.S.A. should be addressed to the Cambridge University Press, American Branch, 32 East 57th Street, New York, N.Y. 10022 .

For the purchase of early parts of the Transactions and Proceedings, application should be made to the Secretaries, Cambrid ge Philosophical Society, Bene't Street, Cambridge, ENGLAND, and for early parts of Biological Reviews to the Cambridge University Press. All parts of the Proceedings (including the cumulative index to Vols. 1 to 50) and of Biological Reviews are available, and prices of sets or single parts will be quoted on application.

Fellows and Associates of the Society are particularly requested to inform the Secretaries of any change of postal address and to send their subscriptions to the Treasurer, at the Society's office.

All correspondence regarding library exchanges and Fellows' copies should be addressed to the Librarian at the Society's office.

\section{PROCEEDINGS of the CAMBRIDGE PHILOSOPHICAL SOCIETY}

\author{
edited by
}

\author{
C. R. F. MAUNDER
}

in consultation with
J. W. S. CASSELS
E. R. LAPWOOD
J.M. C. SCOTT
H. T. CROFT
L. E. FRAENKEL
P. M. LEE

J.E. ROSEBLADE

1. Proceedings of the Cambridge Philosophical Society is published bi-monthly. Three issues form a volume and two volumes are published each year. The subscription price (which includes postage) of a volume is $£ 710 s$. net ( $\$ 24.50$ in the U.S.A.). Papers in all branches of mathematics (including applications of mathematics in the natural and biological sciences) are within its scope.

2. Contributions for the Proceedings should be sent to the Mathematical Secretary at the Society's office (see above). Papers should be communicated directly by the author.

3. Papers which (if printed) would occupy more than 20 pages can only rarely be accepted.

4. Papers in languages other than English should be accompanied by a brief summary in English.

5. It is extremely helpful if diagrams are drawn in indian ink on white card, faintly blue or green-lined graph paper, or tracing cloth or paper. Symbols, legends and captions should be given on a transparent overlay. The Society recognizes that many authors do not have the facilities for producing drawings of a sufficiently high standard to be reproduced directly and it is therefore willing to have such diagrams re-drawn, provided they are reasonably clear.

6. References should be listed at the end of each paper. Titles of journals should be abbreviated as in Mathematical Reviews. Any systematic method of ordering the list of references is acceptable.

7. Authors are particularly requested to prepare their manuscripts in a form suitable for printing, with adequate margins. The Secretary reserves the right to return scarcely legible manuscripts to the author. A pamphlet on the preparation of manuscripts may be obtained on application to the Librarian. If a large number of corrections are required in the proofs, the Council reserves the right to make a charge towards the cost

8. Authors may receive on request 100 free offprints (for each set of authors in the case of a joint paper). Alternatively authors may have 50 free offprints in covers. Further copies may be obtained at reasonable cost. An order form is included with the galley proofs of each paper.

9. Second class postage paid at New York, N.Y. 